\title{
Analyzing the Structure of Administrative System of Hormozgan and its Adaptation to the Perspective of 1404 with the Land Use Planning Approach
}

\author{
Análisis de la estructura del sistema administrativo de \\ Hormozgan y su adaptación a la perspectiva de 1404 con el \\ enfoque de planificación territorial
}

\author{
Mostafa Zaeri Zadeh \\ Department of Management, Kerman Branch, Islamic Azad University, Kerman, Iran. \\ ORCID: https://orcid.org/0000-0002-2572-8239 \\ Masoud Pourkiani* \\ Assistant Professor, Department of Management, Kerman Branch, Islamic Azad University, \\ Kerman, Iran. \\ ORCID: https://orcid.org/0000-0002-5370-3768 \\ Aflatoon Amiri iD \\ Assistant Professor, Department of Management, Kerman Branch, Islamic Azad University, \\ Kerman, Iran. \\ ORCID: https://orcid.org/0000-0003-2413-4313 \\ Saeed Sayadi \\ Assistant Professor, Department of Management, Kerman Branch, Islamic Azad University, \\ Iran. \\ ORCID: https://orcid.org/0000-0003-2917-9043
}

Received 02-08-20 Revised 04-10-20

* Correspondence

Email:pourkiani@iauk.ac.ir
Accepted 01-11-21 On line 01-17-21
Citation:

Zaeri Zadeh M. Pourkiani M. Amiri A. Sayadi S. (2021). Analyzing the Structure of Administrative System of Hormozgan and its Adaptation to the Perspective of 1404 with the Land Use Planning Approach. Propósitos y Representaciones, 9 (SPE1), e884. Doi: http://dx.doi.org/10.20511/pyr2021.v9nSPE1.884 


\section{Summary}

The present study aimed to analyze the structure of administrative systems in Hormozgan and its adaptation to the 1404 perspective with the land use planning (land preparation) approach. This paper is applied in purpose and is descriptive-analytical in nature. The statistical population of this research is Hormozgan as one of the Iran provinces. In order to collect information on the theoretical foundations and research literature, library resources, articles and required books were used and indicators of the administrative system structures (staff, development budget, planning system, spatial structure and free zones) were identified. The required quantitative data was extracted and classified based on census and housing results during 2006- 2017 and after quantitative calculations, they were analyzed in order to adjust with the 1404 goals. In order to analyze the information, time series and factor analysis methods and central tendencies and dispersion were used. SPSS version 24, MINTAB version 17, AMOS version 24 and excel were used for data analysis. Based on the results, considering that there was a significant difference between the value of the mean calculated for each of the factors of the administrative system structure during 2006-2017 (the current administrative system of Hormozgan) and the values related to the administrative system of perspective 1404, so it can be said that there is a difference between the current administrative system of Hormozgan and the perspective of 1404 with the land use planning approach.

Keywords: Political Systems, Perspective of 1404, Land Use Planning, Hormozgan Province.

\section{Resumen}

El presente estudio tuvo como objetivo analizar la estructura de los sistemas administrativos en Hormozgan y su adaptación a la perspectiva 1404 con el enfoque de planificación del uso del suelo (preparación del suelo). Este artículo se aplica con un propósito y es de naturaleza descriptiva-analítica. La población estadística de esta investigación es Hormozgan como una de las provincias de Irán. Para recopilar información sobre los fundamentos teóricos y la literatura de investigación, se utilizaron recursos bibliotecarios, artículos y libros requeridos y se identificaron indicadores de las estructuras del sistema administrativo (personal, presupuesto de desarrollo, sistema de planificación, estructura espacial y zonas francas). Los datos cuantitativos requeridos se extrajeron y clasificaron con base en los resultados del censo y vivienda durante el período 2006-2017 y luego de cálculos cuantitativos, se analizaron para ajustarlos con las metas 1404. Para el análisis de la información se utilizaron métodos de análisis factorial y de series de tiempo y tendencias centrales y dispersión. Para el análisis de datos se utilizaron SPSS versión 24, MINTAB versión 17, AMOS versión 24 y Excel. Con base en los resultados, considerando que hubo una diferencia significativa entre el valor de la media calculada para cada uno de los factores de la estructura del sistema administrativo durante el período 2006-2017 (el actual sistema administrativo de Hormozgan) y los valores relacionados con el sistema administrativo de perspectiva 1404, por lo que se puede decir que existe una diferencia entre el sistema administrativo actual de Hormozgan y la perspectiva de 1404 con el enfoque de ordenamiento territorial.

Palabras clave: Political Systems, Perspective of 1404, Land Use Planning, Hormozgan Province. 


\section{Introduction}

Every country faces different issues and problems in the path of development, and in order to figure out them, it is necessary to think of appropriate measures and solutions. In this regard, planning can be used as a development strategy. However, it should be noted that although in some cases, development problems are easily identifiable and can be addressed through specific measures, in many cases, the situation is more complex and requires planning at all levels (Siti, 2017).

Today, thinking about the spatial organization of countries based on the capacity of the soil, population, the activities of actors and agents is in the field of operation and implementation, which can provide a good platform for development. Because land preparation connects the geographical dimension to economic, social and cultural dimensions, it is placed in the framework of spatial planning. This program, which has a long-term horizon, forms the boundary between macro-plans and regional plans. In other words, the land preparation program links regional programs to national programs (Hosseinzadeh \& Meskini, 2008).

The structure of increasing centralism and mastery of top-down planning, partial approach to planning, ambiguity in the legal status and executive guarantee of provincial planning, lack of necessary and desirable platforms to attract public and private sector participation and etc. have been major obstacles to the development of provincial planning in Iran (Seif al-Dini \& Panahandehkhah, 2010).

The new approaches in the theory of provincial development have a great importance to the institutional and socio-economic structures of the provinces and the differences within them. Accordingly, the development of a province is related not only to its physical resources, but also to its institutional resources (Masoumi Eshkevari, 2006).

Independent study of provinces, especially in terms of administrative systems, will have important results in terms of the existence of the first urban complication and the concentration of services and activities in a city, the tendency to disorder and migration from rural to urban and low attraction of small cities. Therefore, it seems that the study of unbalanced development of provinces in terms of analysis of administrative decisions, including administrative decisionmaking system, service status of executive bodies, manpower, communication infrastructures, transportation, etc. will bring valuable results (Saniei, 2011).

\section{Literature Review}

According to the results of the article presented at the first National Conference on New Approaches to Land Preparation in Iran at Semnan University entitled "Pathology of Land Preparation Plans in Iran", (Andersson et al., 2015) considers the lack of precise definition of the plans status and preparation view in legal documents of guiding programs and decisions in the field of management, oil economy governance and the rental economy as the main components of failure in institutionalizing the regional-spatial view in the structural field and the traditional planning system in accepting a land preparation approach based on the content. They consider the depth of regional inequalities as one of the most important factors in the pathology of land preparation plans in the field of administrative and political structures (Zeng Douglas, 2015).

(Azimi, 2011) in an article on urban and regional planning examined the sustainable development approach. This study, which aimed to investigate and explain the relationship between urban planning and sustainable development, seeks to answer questions such as what is the concept of sustainable development? And what kind of planning can be a sustainable development approach? The findings of this study indicated that participatory planning can be a good method in the study of sustainable development of the city and in this regard, a bottom-up planning approach based on empowerment, emphasis on human resources and collective participation of neighborhood residents can be considered as a basis for sustainable urban development. In this article, he also considers continuity and sustainability as the benefits of participation, which requires the interaction and cooperation of the government, planners and 
the people for whom it is planned. In general, his findings indicate that in any country, especially developing countries, where limited financial and human resources are obstacles to the implementation of plans and programs, bottom-up planning is considered as a sustainable development approach (Tofigh, 2005).

(NIJKAMP, 2001) studied the factors affecting the performance of free trade-industrial zones in Iran. This study showed that despite the apparent differences in the titles, according to the structures of each factor, there is a great agreement between the influential factors in the two regions. According to the findings of this study, the effectiveness of the performance of free and commercial zones was mostly dependent on executive and policy requirements .

(González et al., 2014) in a study investigated the challenges and obstacles of regional development planning in Iran. The results of this study showed that the main obstacle to provincial development in the country is its planning system. Centralization, partisanship, lack of planning culture at management levels, lack of legal framework, dependence on oil revenues, lack of data and information resources, weakness in planning and lack of expertise in the planning system have been among the features of this planning system. In addition, the lack of a good urban governance approach and also the lack of understanding or poor understanding of its importance in establishing a proper management and planning system has exacerbated this shortcoming.

(Armand, 2015) addressed the issue of heterogeneity of spatial structure and irregular situations created in Qorveh region. Then, by choosing a decentralized strategy, they proposed a balanced residential space according to the facilities and capacities of each of them and tried to draw the spatial elements required by the main biological centers in each level, service centers and service constraints, main uses and infrastructure networks in three scales of regional (city), zonal (district) and rural systems.

(Parsapour, 2010) in a study entitled" Development of Free Zones from a legal perspective in Kosovo, examined the legal framework of free zones, the way of regulating executive laws and monitoring the development of free zones, rights and obligations of executives, customs procedures and taxes in 10 free economic zones in eight states. They concluded that the competition between local businesses is not so great despite the existing legal framework and the results and effects of the free zones of that country, because those areas of do not have the essential effectiveness. Therefore, a national strategy that can take into account the standards of international trade can greatly increase the performance of these types of regions.

In a study, (BUTTON, 2016) examined the obstacles and growth factors of small towns in the Polish provinces and acknowledged that the country's development opportunities depend on the state of spatial justice and administrative structures. He attributed the development of small towns to the tourism economy, recreation and leisure, developed technical infrastructure (mainly housing), health, education, cultural role, close proximity to large cities, economic activities and public welfare support policies with spatial change and change in administrative and political structures.

\section{Materials and Methods}

The present study is applied in purpose and is descriptive-correlational in nature. The population of this study is Hormozgan province as one of the provinces of Iran. This province is placed in the South of Iran and north of Strait of Hormuz. The boundaries of this province in the east face Oman Sea and in the west face Persian Gulf. Some of the important Islands of Hormozgan are Qeshm, Kish, Abu Musa, Lavan, Hormuz, Larak and Siri. It has 13 counties, 23 cities, 33 districts, 71 rural districts and 2170 villages. According to the conducted census in 2017, the population of Hormozgan province is 1776415 people. It is located between the geographical coordinates of $25^{\circ} 24^{\prime}$ to $57^{\circ} 41^{\prime}$ north latitude and $53^{\circ} 41^{\prime}$ to $59^{\circ} 15^{\prime}$ east longitude 
of Greenwich meridian. Its area is about $68000 \llbracket \mathrm{km} \rrbracket^{\wedge} 2$ which in this regard is the eighth province of the country. Hormozgan is neighbor to Kerman province in north and north east and is neighbor to Sistan and Baluchestan province in east and in west and in north west is near to Fars and Bushehr provinces and its south encompasses Persian Gulf and Oman sea in a strip about $900 \mathrm{~km}$. The counties of Hormozgan province are Parsian County, Bastak County, Bandar Lengeh County, Abumusa County, Qeshm County, Khamir County, Bandar Abbas County, Hajjiabad County, Rudan County, Minab County, Sirik County, Bashagard County and Jask County. There is no statistical sample in this research and census (complete enumeration) is used here. In order to collect data in the field of theoretical foundations and research literature, library resources, articles, required books and indicators of the administrative systems structures (Table 1) were identified. In order to collect the required data, the researcher has directly and by referring to the Management and Planning Organization of Hormozgan province gathered the required statistics and information during two months. The quantitative data were extracted and categorized according to the results of population and housing censuses during 2006-2017, and after quantitative calculations, they were analyzed in order to compare with the goals of 1404.

Table 1.

Identified Indicators of the Administrative Systems Structure

\begin{tabular}{cc}
\hline Variables & Factors \\
\hline Administrative system structure & Staff \\
\cline { 2 - 2 } & Development budget \\
\cline { 2 - 2 } & Planning system \\
\cline { 2 - 2 } Spatial structure \\
\hline
\end{tabular}

To analyze the information, time series and factor analysis methods and central indicators dispersion were used. SPSS version 24, MINITAB version 17 and AMOS version 24 and excel were used for data analysis.

\section{Results}

The main question: To what extent can the structure of the existing administrative systems realize the vision of 1404 in Hormozgan province?

Table 2.

The Mean and Predicted Values

\begin{tabular}{|c|c|c|c|c|}
\hline Variables & Factors & $\begin{array}{l}\text { The mean of } \\
2006 \text { to } 2017 \\
\text { years }\end{array}$ & $\begin{array}{l}\text { The vision of } \\
1404\end{array}$ & $\begin{array}{l}\text { The predicted } \\
\text { value in the time } \\
\text { series model }\end{array}$ \\
\hline \multirow{4}{*}{$\begin{array}{l}\text { Administrative } \\
\text { systems structure }\end{array}$} & Staff & 52614.4167 & 107671 & 83495.6781 \\
\hline & $\begin{array}{l}\text { Development } \\
\text { budget }\end{array}$ & 3752393.916667 & 12469400 & 11511078.45 \\
\hline & Planning system & 123 & 175 & 184.67 \\
\hline & Spatial structure & 2643.9167 & 3800 & 3910.339 \\
\hline
\end{tabular}




\section{Free zones}

22703.6667

104702

102393

According to (Table 2), in order to investigate the extent to which the structure of the existing administrative systems can achieve Vision 1404 in Hormozgan province, the amount of correlation between the two columns (Vision 1404) and the predicted values of the time series model were calculated. The correlation is equal to 0.98 because this value is greater than 0.7 and is close to one, so it can be concluded that the structure of the existing administrative systems can largely realize the vision of 1404 in Hormozgan province.

Sub-question 1: What is the status of administrative system of Hormozgan province?

According to (Figure 1) based on the goodness of fit index (GFI), the given fitted model has a good fit. Therefore, it can be said that the indicators for the latent variable are well described.

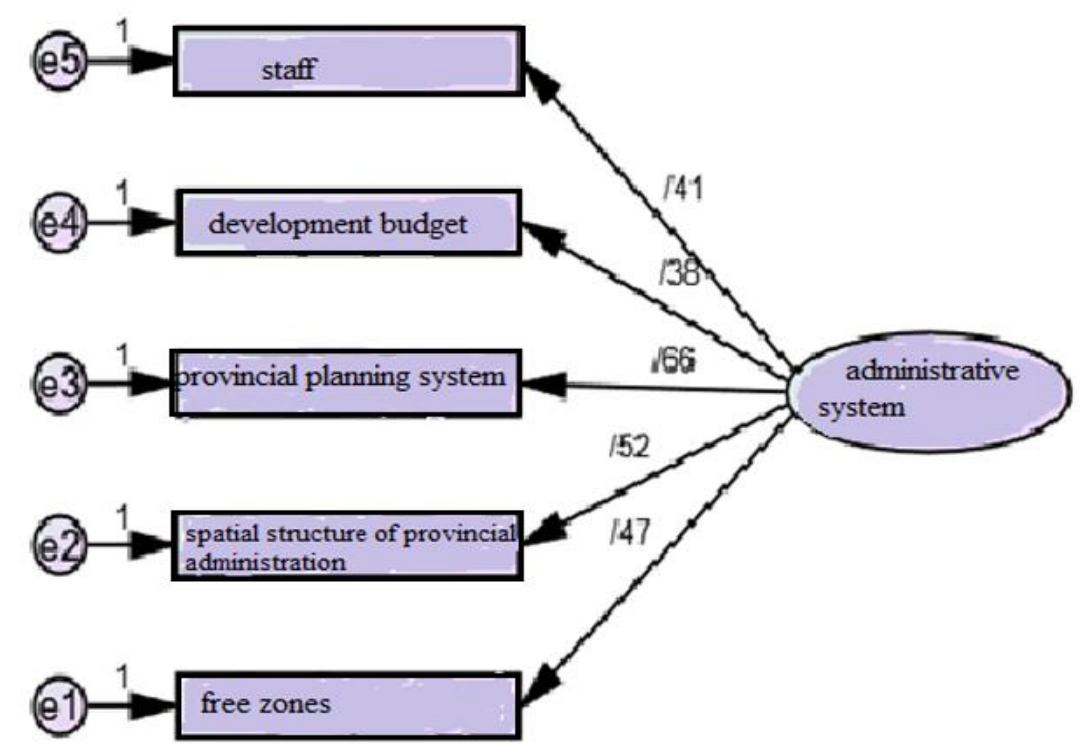

Figure 1. Factor Analysis of Variables of Administrative Systems of Hormozgan

Table 3.

Fit Indicators of the Path Analysis Model of the Variables of Administrative System Factors of Hormozgan Province

\begin{tabular}{lcc}
\hline Index & Optimum statistics & The reported value \\
\hline $\begin{array}{l}\text { Root mean square error of } \\
\text { approximation (RMSEA) }\end{array}$ & $\leq 0.08$ & 0.059 \\
\hline Chi-square ratio & $<3$ & 2.011 \\
\hline Goodness of fit index (GFI) & $\geq 0.90$ & 0.901 \\
\hline $\begin{array}{l}\text { Adjusted goodness of fit } \\
\text { index (AGFI) }\end{array}$ & $\geq 0.90$ & 0.979 \\
\hline Comparative fit index (GFI) & $\geq 0.90$ & 0.979 \\
\hline Normed fit index (NFI) & $\geq 0.90$ & 0.922 \\
\hline Tucker-Lewis index(TLI) & $\geq 0.90$ & 0.951 \\
\hline Incremental fit index(IFI) & $\geq 0.90$ & 0.974
\end{tabular}


Researchers consider the root mean square error of approximation (RMSEA) to be less than 0.80 to indicate the suitable fit of the model (Ghasemi, 2013), which in the present study is equal to 0.059 . On the other hand, researcher consider the appropriate relative chi-square to be less than 3 (Ghasemi, 2013), which in the present study is 2.011. The scores of GFI, AGFI, RMSEA, NFI, TLI, IFI, and CFI are between zero and one, which is closer to one, indicating the appropriate fit of the model, although scores above $90 \%$ have the most appropriate fit of the model (Byrne, 1994). In this model, the goodness of fit index value (GFI) is equal to 0.901, the adjusted goodness of fit index value is 0.967, comparative fit index value (CFI) is 0.979, normed fit index (NFI) or Bentler-Bonett index is 0.922, non-normed fit index (NNFI) or Tucker-Lewis index (TLI) is 0.951, and incremental fit index (IFI) is 0.974. In general, according to the presented indicators in (Table 3), the model has a good fit.

Sub-question 2: What is the situation of employees in Hormozgan?

According to (Table 4), the mean observed for this variable is equal to (52614.416667), its median is equal to (57315), standard deviation is equal to (15238.012137), the minimum is equal to (24009) and the maximum is equal to (70311).

\section{Table 4.}

Description of Employees Variable among Subjects

\begin{tabular}{llllll}
\hline Variable & Mean & Median & $\begin{array}{l}\text { Standard } \\
\text { deviation }\end{array}$ & Minimum & Maximum \\
\hline Employees & 52614.41667 & 57315 & 15238.012137 & 24009 & 70311 \\
\hline
\end{tabular}

Sub-question 3: What is the status of development budget of Hormozgan province?

According to (Table 5), the mean observed for this variable is equal to (3752393.916667), its median is equal to (2574554.5), standard deviation is equal to (2576806.518558), the minimum is equal to (1893496) and the maximum is equal to (9790668).

\section{Table 5.}

Description of the Development Budget Variable among Subjects

\begin{tabular}{llllll}
\hline Variable & Mean & Median & $\begin{array}{l}\text { Standard } \\
\text { deviation }\end{array}$ & Minimum & Maximum \\
\hline $\begin{array}{l}\text { Development } \\
\text { budget }\end{array}$ & 3752393.916667 & 2574554.5 & 2576806.518558 & 1893496 & 9790668 \\
\hline
\end{tabular}

Sub-question 4: What is the status of planning and decision-making system in Hormozgan province?

According to (Table 6), the observed mean for this variable is equal to (123), its median is equal to (110.50), standard deviation is equal to (70.691391), the minimum is equal to (45) and the maximum is equal to (260).

Table 6.

Description of Planning and Decision-making System Variable among Subjects

\begin{tabular}{llllll}
\hline Variable & Mean & Median & $\begin{array}{l}\text { Standard } \\
\text { deviation }\end{array}$ & Minimum & Maximum \\
\hline $\begin{array}{l}\text { Planning and } \\
\text { decision }\end{array}$ & 123 & 110.50 & 70.691391 & 45 & 260 \\
$\begin{array}{l}\text { making } \\
\text { system }\end{array}$ & & & & \\
\hline
\end{tabular}


Sub-question 5: What is the status of spatial structure of Hormozgan province?

According to (Table 7), the mean observed for this variable is equal to (2643.916667), its median is equal to (2658.50), standard deviation is equal to (302.654156), the minimum is equal to $(2285)$ and the maximum is equal to (3023).

\section{Table 7.}

Description of the Spatial Structure Variable of Hormozgan Province among Subjects

\begin{tabular}{llllll}
\hline Variable & Mean & Median & $\begin{array}{l}\text { Standard } \\
\text { deviation }\end{array}$ & Minimum & Maximum \\
\hline $\begin{array}{l}\text { Spatial } \\
\text { structure }\end{array}$ & 2643.916667 & 2658.50 & 302.654156 & 2285 & 3023 \\
\hline
\end{tabular}

Sub-question 6: What is the status of free zones of Hormozgan province?

According to (Table 8), the mean observed for this variable is equal to (22703.666667), its median is equal to (11091), standard deviation is equal to (23724.69521), the minimum is equal to (6712) and the maximum is equal to (76111).

\section{Table 8.}

Description of the Variable of Hormozgan Province Free Zones among the Subjects

\begin{tabular}{llllll}
\hline Variable & Mean & Median & $\begin{array}{l}\text { Standard } \\
\text { deviation }\end{array}$ & Minimum & Maximum \\
\hline Free zones & 22703.666667 & 11091 & 23724.69521 & 6712 & 76111 \\
\hline
\end{tabular}

Sub-question 7: What is the status of the administrative system of Hormozgan province in the perspective of 1404 ?

Goodness of fit indices for the model related to the dimensions of the factors of the administrative system of Hormozgan province in perspective 1404 are given in (Figure 2). Based on the goodness-of-fit indicators, the given fitted model has a good fit. According to the obtained results, it can be said that the indices for the latent variable are well described. 


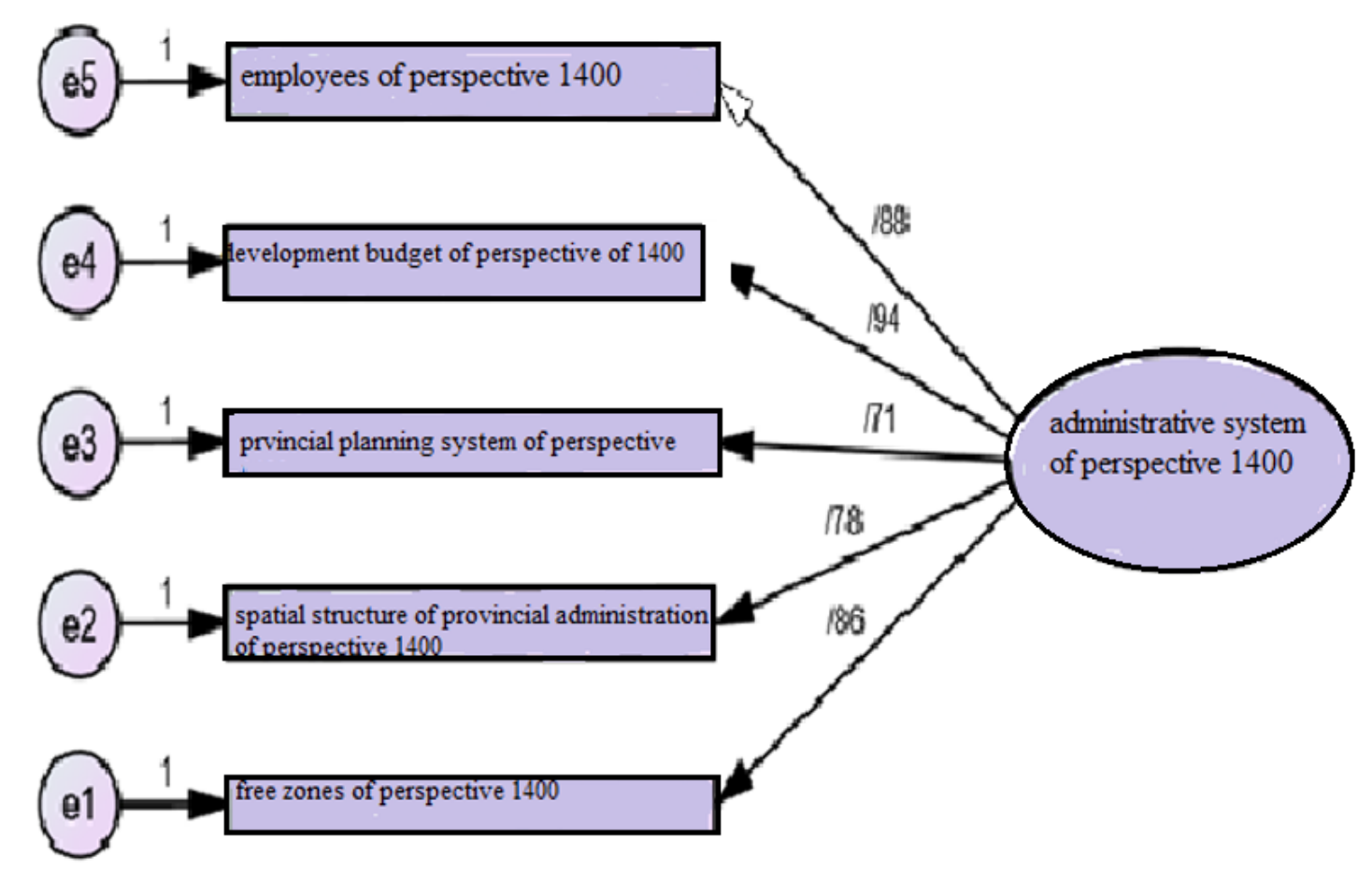

Figure 2. Factor Analysis of the Variable of the Administrative System of Hormozgan Province in the Perspective of 1404

\section{Table 9.}

Fit Indicators of the Path Analysis Model of the Factors of Administrative System Variable of Hormozgan Province in Perspective 1404

\begin{tabular}{ccc}
\hline Index & Optimum statistics & The reported value \\
\hline $\begin{array}{c}\text { Root mean square error of approximation } \\
\text { (RMSEA) }\end{array}$ & $\leq 0.08$ & 0.066 \\
\hline Chi-square ratio $\left(\chi^{2} / d f\right)$ & $<3$ & 2.212 \\
\hline Goodness of fit index $(\mathrm{GFI})$ & $\geq 0.90$ & 0.974 \\
\hline Adjusted goodness of fit index $(\mathrm{AGFI})$ & $\geq 0.90$ & 0.938 \\
\hline Comparative fit index (GFI) & $\geq 0.90$ & 0.929 \\
\hline Normed fit index (NFI) & $\geq 0.90$ & 0.985 \\
\hline Tucker-Lewis index(TLI) & $\geq 0.90$ & 0.956 \\
\hline Incremental fit index(IFI) & $\geq 0.90$ & 0.938 \\
\hline
\end{tabular}

Researchers consider the root mean square error of approximation index (RMSEA) to be less than 0.08 to indicate a suitable fit of the model (Ghasemi, 2013), which in the present study is equal to 0.066 . The value of the relative chi-square $\left(\chi^{2} / d f\right)$ in the present study is 2.212 . In this model, the value of goodness of fit index (GFI) is equal to 0.974, the value of adjusted goodness of fit index (AGFI) is equal to 0.938, comparative fit index (CFI) is equal to 0.929, normed fit index (NFI) or Bentler-Bonett index is equal to 0.985, non-normed fit index (NNFI) or Tucker-Lewis index (TLI) is equal to 0.956 and incremental fit index (IFI) is equal to 0.938 . The model presented in (Table 9) has a good fit.

Sub-question 8: Are there any differences between the current administrative system of Hormozgan province and the perspective of 1404 with the land use planning approach? 
Table 10.

Comparison of the Current Situation of the Factors of Administrative System of Hormozgan Province and the Perspective of 1404

\begin{tabular}{llll}
\hline Variables & Factors & $\begin{array}{l}\text { The mean of 2006 to } \\
2017\end{array}$ & $\begin{array}{l}\text { The perspective of } \\
1404\end{array}$ \\
\hline $\begin{array}{l}\text { Administrative } \\
\text { systems structure }\end{array}$ & Staff & 52614.4167 & 107671 \\
\cline { 2 - 4 } & $\begin{array}{l}\text { Development } \\
\text { budget }\end{array}$ & 3752393.916667 & 12469400 \\
\cline { 2 - 4 } & Planning system & 123 & 175 \\
\hline & Spatial structure & 2643.9167 & 3800 \\
\cline { 2 - 4 } & Free zones & 22703.667 & 104702 \\
\hline
\end{tabular}

\section{Conclusion}

This study aimed to review the current situation and provide a suggestion in order to achieve the goals of administrative systems in line with goals of perspective1404 in Hormozgan province, which is described in the following.

1. Staff: Continuous improvement of organizations today is the key to achieve quality and productivity, and this will not be possible unless with the participation of all employees. The most effective system for attracting the participation of employees and other people related to the organization is suggestion review system (POON, 2006).

Since the current situation of the employees in this study is different from the perspective goals of 1404 and the land preparation approach, so pay attention to the development of people, infrastructures and requirements to provide the ground for change in operational and managerial methods to achieve this is necessary.

2. Budget: About $25 \%$ of the total public resources of the government (940 thousand billion rials) are provincial revenues and about $18 \%$ of the total public expenditures (660 thousand billion rials) are provincial credits which are allocated through the mechanism of provincial expenditure revenue system. However, for most of these credits, which were previously national and provincialized in the 2017 budget bill (about 68\%), certain tables have been identified separately for the provinces, and the reduction of these credits has been banned by the Provincial Planning and Budget Organization. These credits include the expenditure credits of the two departments of education (331 thousand billion rials) and Foundation of Martyrs (114 thousand billion rials) as well as the Provincial Planning and Budget Organization (9.2 thousand billion rials). In this report, the credits that are allocated centrally to the provinces through the ministries are not considered.

According to the total conditions of the provincial budget and the rank of the provinces in the allocation of credits related to the affairs of the provinces, which are presented in the report, the following items are suggested:

Calculation of $3 \%$ of revenues from exports of crude oil and natural-gas condensate and net exports of natural gas: According to the law, the basis for calculating 3\% of oil revenues is: revenues from exports of crude oil and gas condensates and net exports of natural gas, which must be calculated before deducting the share of the National Oil Company and the share of the fund. With the assumptions of the budget bill of 2017, the minimum share of deprived and oilrich areas will be 6.56 thousand billion rials, which should be listed in row 210109, while this figure is listed in the budget bill of 2017 as 8.50 thousand billion rials. Furthermore, as explained in the text, according to the resources considered in row 160139 of (Table 5) of the budget bill, 6.5 thousand billion rials should have been added to the $3 \%$ share of the mentioned 
areas. Therefore, in total, it can be said that the credits related to this issue have been underestimated 12 thousand billion rials.

Real increase in the decision-making capacity of the provinces in allocating the budget: In the Budget Law of 2017, about $94 \%$ of the budget credits were allocated centrally and all provinces had a $6 \%$ role in allocating the credits, which is done through the provincial expenditure revenue system mechanism.

In the budget bill of 2018, although the share of decentralized decision-making in the provinces has apparently increased to $18 \%$, severe restrictions have been placed on the major part of these credits so that $68 \%$ of these credits are related to expenditure credits (mainly salaries and wages) of Education Department and Foundation of Martyrs and the provincial Planning and Budget Organizations, and the mentioned bill prohibits the reduction of these funds by the provincial Planning and Budget Organization. Although this has been arranged by provincial managers to deal with the problems of not allocating these credits to these organizations and giving priority to some other organizations, thus increasing provincial credits does not mean an increase in the decision-making capacity of provinces.

The need for more connection between the distribution of expenditure and development credits to less privileged provinces with the per capita criteria: At present, the ranking of provinces based on per capita expenditure credits and per capita of capital asset acquisition credits does not indicate more allocation to non-privileged provinces. It is necessary to examine the effectiveness of policies to reduce the development gap in recent years through the mechanisms of distribution of credits in the budget (such as credits of $3 \%$ of oil and gas revenues and credits to the law of balanced use of the country's resources, which is $3 \%$ of public budget resources).

Allocation of credits of the law of balanced use of the country's facilities has existed from the law of the fourth plan and since (2015), these credits have increased from $2 \%$ to $3 \%$ of budget resources. In addition, there have been credits of $3 \%$ of oil and gas revenues since 2006 with the aim of eliminating deprivation which in 2017 , the share of these credits increased from $2 \%$ to $3 \%$ and the basis for its calculation was changed to before deducting the share of the Development Fund and the share of the National Oil Company. The successive increases in the credits related to the elimination of deprivation raise the fundamental question of whether the allocation of these credits during the mentioned period has been able to bring the less privileged provinces closer to the average development of the country and reduce the development gap between the provinces or not?

Establishing incentive mechanisms for state-owned enterprises to invest in deprived and less privileged regions:

The geographical distribution of state-owned enterprises and their investments, as well as private companies that were previously state-owned and transferred, are effective in differentiating the level of development of the provinces. Accurate statistics on the geographical distribution of state-owned enterprises and, consequently, the provincial breakdown of stateowned enterprises' credits are not available, but statistics on state-owned enterprises taxes show that the share of central provinces is higher than that of border and marginal provinces, which shows the economic activity of state-owned enterprises in these provinces.

Necessity of changing the view of the country's water management:

Considering the problem of water crisis that the country is facing, strengthening the infrastructure related to this area is an important issue that has been considered in the allocation of special provincial credits approved by law. However, a review of the relevant plans shows that most of these credits have been allocated for the construction or rehabilitation of dams.

The next suggestion in this regard with the budget is that according to the parity index, which tries to make the different provinces of the country reach an almost equal level in terms of access to facilities based on capabilities and the current situation, and differences due to incorrect budget allocation, in the last periods be compensated and considering that some provinces such as Hormozgan province do not have the ground to attract even if the budget is allocated, so the use of efficiency index makes the ability to attract the budget and infrastructure of each province in the budget allocation is also considered. In fact, by combining these two 
indicators, the budget allocation criteria will be reasonable and appropriate. The results of this estimate show that tactical and programmatic variables have a positive and significant effect on the ownership budget of the capital assets of the provinces.

3. Spatial: Spatial planning is based on scale and with emphasis on the various capabilities of spatial systems, from local communities and regions to the national level and can include rural, urban and regional planning together. In other words, spatial planning strives to maintain and protect the necessary quality in urban and rural areas. Of course, it is clear that spatial planning issues are not always the same, but change with the characteristics of societies and their development.

If we pay attention to the principles and laws governing the structural-functional dynamisms and the main goals of spatial planning, a close compatibility between these two cases will be observed. Based on this, the main goals of spatial planning and, consequently, what structuralfunctional dynamism seeks to identify are as following:

-Modification of spatial structures with special attention to the natural environment and socioeconomic characteristics of spatial systems (region, district, city and village).

- Spatial arrangement of various socio-economic activities at different levels of the land; and regulation of spatial relations and functions through hierarchical leveling of urban and rural settlements.

4. Planning: In order to make a strategically plan, urban and regional planning with a participatory approach needs to achieve a series of priorities, which the most important of them are as following:

-Supporting local councils and associations and facilitating their activities

- Understanding the current status process, identifying needs and prioritizing participatory methods

-Identifying the key influential groups in local decision-making, establishing close and continuous communication with them, and incorporating their views into planning

- Identify and adjust the existing differences between the beneficiaries through active dialogue between all parties

-Exchange of information between all parties actively, comprehensively and continuously

- Setting general planning policies that are agreed upon by all stakeholders.

- Record the commitments of all parties involved in a transparent manner and specify a mechanism to ensure compliance.

-Develop a mechanism to monitor urban executive plans by citizens

- Creating a mechanism for continuous and inclusive cooperation of residents in the implementation process

According to the mentioned strategies, it can be concluded that the most important principle in urban and regional planning with a participatory approach is to pay special attention to the demands and interests of the people for whom planning is done.

5. Free Zones: New marketing, the existence of export marketing cooperatives, allocation of development and current costs for the construction of infrastructures in the region, the stability of exchange rate policies and the establishment of credible monetary and banking institutions as economic factors; Existence of water infrastructure facilities and energy carriers, existence of communication infrastructures such as telephone, internet, post, etc., existence of transportation infrastructure, existence of airport infrastructure, provision of educational services and export consulting, existence of suitable warehouses and provision of public services as infrastructure factors; Stability in decisions, adoption of production strategy and development of the country's exports, management stability, simplification of customs export processes, overseas services including providing services to main customers, adequate budget allocation for regions by the government and coordination and adaptation of foreign policy with the changes of International economics under the heading of management systems; Tax exemptions applied in order to develop productive activities, grant banking facilities with low interest rates, provide insurance services and exemptions from duties and customs imposed in the framework of legal systems; Supply of raw materials and cheap labor, correct location, political and cultural situation of the 
country in the world arenas, economic stability of the country, existence of serious competitors in the region and political stability of the country as environmental factors can lead the performance of free zones of Hormozgan province to productivity.

\section{References}

Siti N. (2017), Sterategic human resource planning: responding to changes dynamic business environment and effective to achieve competitive advantage-macrothink institute, Jornal of social science studies, 4(2): 336-342.

Hosseinzadeh D. \& Meskini M. (2008), Regional Planning and its Role in Human Development of the Provinces. Quarterly Journal of Social Sciences, 44(6): 15-29.

Seif al-Dini M. \& Panahandehkhah K. (2010), Challenges and Obstacles of Regional Development Planning in Iran, Journal of Human Geographical Research, 19(3): 77-85.

Masoumi Eshkevari M. (2006), The New Role of Regional Development in the Era of Global Convergence, Program Magazine, 9(2): 120-133.

Saniei A. (2011), Land Use planning a Way to the Balance of the Urban System and Development, Quarterly Magazine of Reviewing Economic Issues and Policies, 8(2): 89-110.

Andersson E. \& Nykvist B. \& Malinga R. \& Jaramillo F. \& Lindborg R. (2015), A social ecological analysis of ecosystem services in two different farming systems, Ambio, 4(4): 102-112.

Zeng Douglas Z. (2015), "Global Experiences with Special Economic Zones: Focus on China and Africa", World Bank Policy Research Working Paper, 16(3): 180-196.

Azimi A. (2011), Iran's economy. Development, Planning, Politics and Culture, Nei Publication, 8(3): 186-193.

Tofigh F. (2005), Land Use Planning of Global Experience and its Adaptation to the Situation in Iran, Tehran: High Secretariat of Urban Planning and Architecture of the Ministry of Housing and Urban Development, 21(2): 136-140.

NIJKAMP P. (2001), "Suzhou Technology Park", Research note for WBI Development Series, China and the Knowledge Economy: Seizing the 21st Century, Washington, DC: World Bank, 8(6): 59-66.

González S. \& Yáñez-Nevea K. \& Muñoz M. (2014), Effect of coastal urbanization on Sandy beach coleóptera Phaleria maculata in northern Chile, Universidad Católica del Norte. Coquimbo, Chile, Marine Pollut. Bull, 16(1): 265-274.

Armand K. (2015), Free economic zones from the legal, Perspective in Kosovo, academic jornal of inter displinary studies, 8(3): 99-110.

Parsapour R. (2010), Land Preparation of Bandar Abbas-Persian Gulf Studies Center, Quarterly Magazine of Persian Gulf and Security, 5(9): 140-151.

BUTTON K. (2016), special economic zonesilessons from the global experience, PEDL, synthesis paper servies, 11(5): 79-90.

Ghasemi H. (2013), "An Overview of Six Economic Zones in Nigeria: Challenges and Opportunities", World Bank Policy Note, 20(4): 134-140.

Byrne S. (1994), Strategic human resource planning in academia American journal of business education, 12(7): 184-204.

POON J. (2006), SOCIAL PLANNING, P. 216 LONDON, AN ELGAR REFRENCE COLLECTION PRESS, 13(7): 365-374. 